\title{
Lemthang Tsho glacial Lake outburst flood (GLOF) in Bhutan: cause and impact
}

\author{
Deo Raj Gurung ${ }^{1 *}$, Narendra Raj Khanal ${ }^{1,2}$, Samjwal Ratna Bajracharya ${ }^{1}$, Karma Tsering $^{3}$, Sharad Joshi', \\ Phuntsho Tshering ${ }^{3,4}$, Lalit Kumar Chhetri ${ }^{4}$, Yeshey Lotay ${ }^{5}$ and Tashi Penjor ${ }^{6}$
}

\begin{abstract}
Background: The Hindu Kush Himalayan $(\mathrm{HKH})$ region being seismically active and sensitive to climate change is prone to glacial lake outburst flood (GLOF). The Lemthang Tsho GLOF breached in the evening of 28 July 2015 innorth-western Bhutan is reminds of the looming threat, and stresses the need to have good risk management plan. The need to understand the physical processes in generating GLOF to is therefore imperative in order to effectively manage the associated risk. The paper therefore assesses the cause and impact of the Lemthang Tsho GLOF event using field and remote sensing data.
\end{abstract}

Results: The collapse of near vertical wall of supraglacial lake triggered by 2 days of incessant rainfall, opened up the englacial conduit resulting in emptying of interconnected supraglacial lakes into Lemthang Tsho. The5.1 magnitude earthquake epicentered $187 \mathrm{~km}$ to southeast in the Indian state of Assam in the morning (7:10 am Bhutan Standard Time) of the same day is unlikely to have played any role in triggering the event. The estimated volume of water unleased is 0.37 million $\mathrm{m}^{3}$, with peak discharge estimated to be ranging from 1253 to $1562 \mathrm{~m}^{3} / \mathrm{s}$, and velocity of $7.14-7.57 \mathrm{~m} / \mathrm{s}$. The impact was minimal and confined up to $30 \mathrm{~km}$ downstream from the lake. The flood took lives of 4 horses, washed away 4 timber cantilever bridges, 148 pieces of timber, damaged 1 acre of land, and washed away $1 \mathrm{~km}$ of trail. The team also monitored 3 out of 25 identified critical glacial lakes and downgraded the risk of all 3 critical glacial lakes based on the finding. This brings the number of critical glacial lakes in Bhutan to 22.

Conclusion: The threat of GLOF still looms large in the Himalaya, particularly in view of impact of climate change and frequent seismic activities. There is a need for good risk management practices which starts fromidentification of critical glacial lakes, to prioritize in-depth investigation. As the present list of critical glacial lakes are largely based on inventory done over a decade based on topographic maps some of which datedback to 1960s, we need to revisit the critical glacial lakes and assess the risk considering recent changes. The new assessment needs to consider supraglacial lakes as one of the criteria in evaluating the GLOF risk, as highlighted by the Lemthang Tsho GLOF.

Keywords: Glacial lake, Glof, Mountain hazard, Climate change, Natural hazard, Bhutan

\section{Background}

The glacial lake outburst flood (GLoF), a phenomenon characterized by release of huge volume of water as a result of an outburst of a glacial lake, is one of the important natural hazard (Ives 1986). The outburst happens when the confining moraine wall of unconsolidated material often underlain by dead ice is unable to contain

\footnotetext{
* Correspondence: deoraj.gurung@icimod.org

${ }^{1}$ International Centre for Integrated Mountain Development, Khumaltar,

Lalitpur, Nepal

Full list of author information is available at the end of the article
}

the huge body of water, thus resulting in sudden release of water which can be of the order of several million cubic metres. The volume of water unleased is estimated as 5 million cubic metres in case of Dig Tsho GLOF in 1998 (Vuichard and Zimmermann 1987), 437,000 cubic metres in case of western Zyndan GLOF in 2008 (Narama et al. 2010), 18 million cubic meters in case of Luggye Tsho in 1994 (WWF 2009). Such outbursts in the past resulted of deluge with peak discharge of $10,000 \mathrm{~m}^{3} / \mathrm{s}$ in case of Sangwang-Cho (Daoming and Qinghua 1994), $15,920 \mathrm{~m}^{3} / \mathrm{s}$ in case of Zhangzangbo 
GLOF (Xu 1988), and $10 \mathrm{~m}^{3} / \mathrm{s}$ in case of Lake No. 3 of Gruben area Switzerland (Haeberli et al. 2001), and $2500-3600 \mathrm{~m} 3 / \mathrm{s}$ in case of GLOF from glacial lake LC2 in Patagonia, Chile (Jacquet et al. 2017). The GLOF can attain peak discharge of $30,000 \mathrm{~m}^{3} / \mathrm{s}$ and travel distance in access of $200 \mathrm{~km}$ (Richardson and Reynolds 2000), and traverse with very high velocity. The estimated velocity is $10 \mathrm{~m} / \mathrm{s}$ in case of Damenhai-Cho GLOF (Ding and Liu 1992), $7-17.9 \mathrm{~m} / \mathrm{s}$ in case of Zhangzangbo GLOF (Xu 1988), $5-10 \mathrm{~m} / \mathrm{s}$ in case of Tam Pokhari is (Osti and Egashira 2009; Dwivedi et al. 2000). Therefore, the impact from the high speed deluge extends far beyond the site of origin and often attains catastrophic dimensions resulting in significant loss of lives, and widespread damage to properties, and inflicting long term socio-economic and environmental challenges as experienced in past events (Liu et al. 2014; Khanal et al. 2013; Asraf et al. 2012; Carey et al. 2012; Haeberli 1983; Hewitt 1982). The Luggye Tsho GLOF saw 20 lives being lost apart from damage to 12 houses, 5 watermills, 4 bridges and 816 acre of dry land (WWF 2009). The GLOF from Guangxieco Lake in Tibet, China killed 5 people, swept away 51 houses, and destroyed a ranch and a 6.7 ha farm in Midu Village (Luo and Mao 1995). The Dig Tsho GLOF washed away then recently completed hydropower. As recent as 5 July 2016 the GLOF originating from Chinese side of the border hit Bhote Koshi (Cook et al. 2017) and swept at least two dozen river side homes and parts of the Araniko Highway (Kathmandupost, dated: 22 January 2017). An outburst event in 1941 in Peru killed almost 4500 people in the city of Huaraz (Lliboutry et al. 1977). Luggye Tsho GLOF generated flood height of over $2 \mathrm{~m}$ at distance of $200 \mathrm{~km}$ downstream of the source (Richardson and Reynolds 2000). The destruction and damage in monetary valuation ranges in millions of US Dollar. The estimated cost, including the destruction of the hydropower plant, has been estimated at around $\$ 500$ million in case of Dig Tsho GLOF (Shrestha et al. 2010). With growing urban sprawling in fertile valley and investment on high values infrastructures such as hydropower plants, the damage will escalate further in case of future GLOFs.

Enhanced glacier melting due to rising temperature influences formation and enlargement of glacial lakes, a direct connection between climate change and increased GLOF risk. Although the glacial lake area has been reported to have increased in the Himalayas between 1990 and 2009 (Gardelle et al. 2011), the increase in GLOFs events in recent decades is not certain yet (Komori 2012;

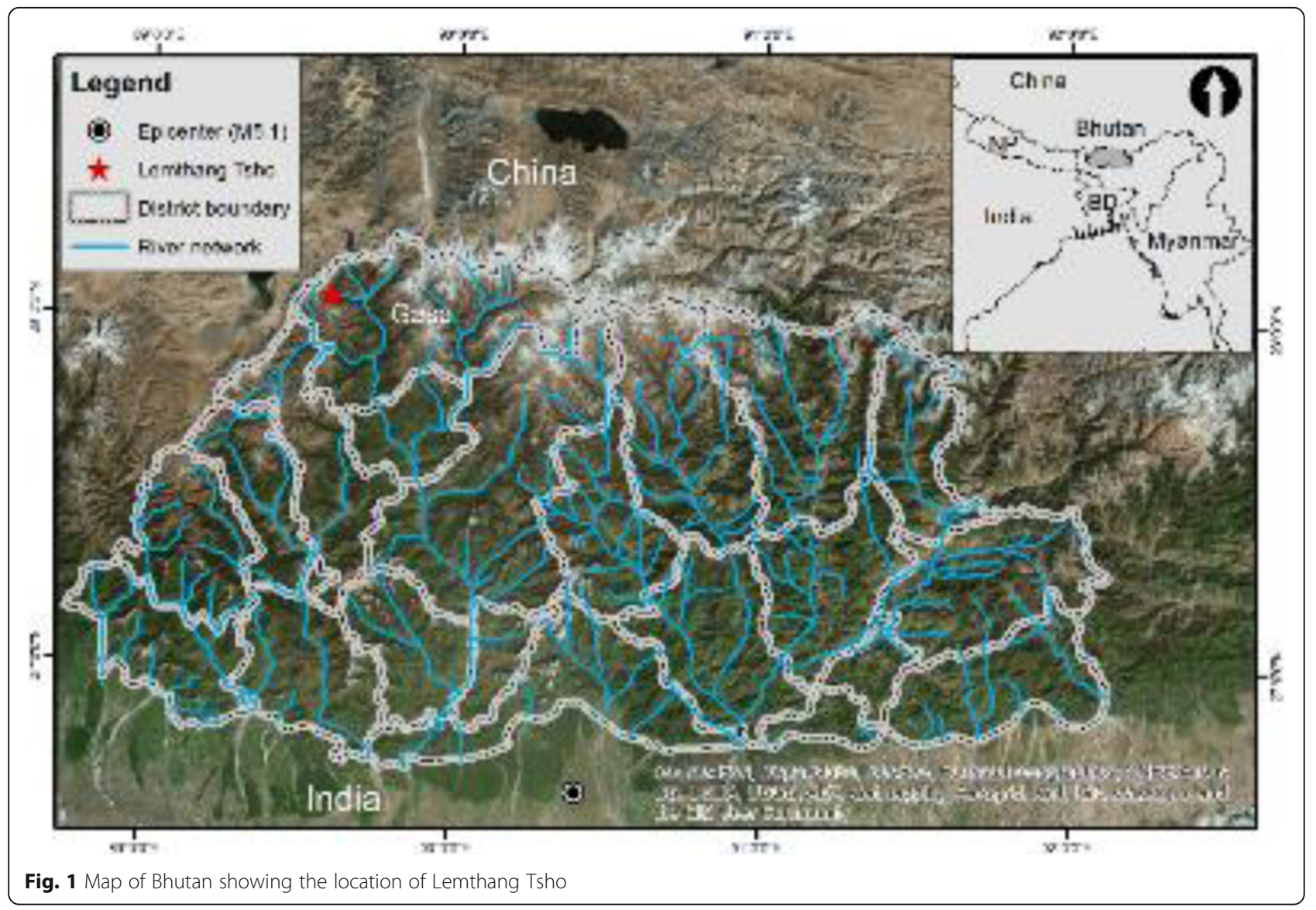


Richardson and Reynolds 2000). However, enhanced ice melt at the margins of receding glaciers due to observed warming trend and increase in weather extremes: rainfall and temperature (Field 2012) have increased the likelihood of GLOF events (Crammer 2014; Field 2014; Riaz et al. 2014). The HKH region has been witnessing GLOF events from time to time one of which is the Lemthang Tsho GLOF of 28 June 2015 in north-eastern part of Bhutan. Understanding of outburst mechanism of GLOF is critical to our effort to minimize risk, and such real cases provide an excellent opportunity to do so. This paper discusses cause and impact of the GLOF event based on remote sensing analysis and intensive fieldwork.

\section{Study area}

The Lemthang Tsho is located in a remote location defined by longitude $89^{\circ} 34^{\prime} 53.42^{\prime \prime}$ and latitude $28^{\circ} 04^{\prime}$ 05.17", in north-western part of Bhutan in Gasa district (Fig. 1). It is tugged at an elevation of $4270 \mathrm{~m}$ asl, and is $6 \mathrm{~h}$ (on foot) away from nearest settlement Laya village and 3 days walk from road head (Gasa town). The lake is positioned in the frontal part of north-west to southeast trending glacier. The lake was mapped as Mo_gl_200 in 2001 inventory (Mool et al. 2001). The lake drains into
Mo Chu (river) which ultimately joint Pho Chu to form Puna-Tsang Chu.

Geologically the study area lies in Greater Himalayan Zone, a crystalline belt mainly consisting of gneiss with occasional intercalation of marble, limestone and leucogranites (Long et al. 2011). The basement lithology in the vicinity of the lake has north-east to south-west trending strike with south-east trending dip with dip angle ranging from $25^{\circ}$ to $30^{\circ}$. An east-west trending and north dipping thrust, the Laya Thrust runs close by the lake.

The climate there is temperate type with warm summer and very cold winter. Mean summer temperature ranges from $12{ }^{\circ} \mathrm{C}$ to $14{ }^{\circ} \mathrm{C}$ while winter temperature ranges from $-2{ }^{\circ} \mathrm{C}$ to $-6{ }^{\circ} \mathrm{C}$ (Dorji et al. 2016). Annual precipitation is in the order of $1801 \mathrm{~mm}$ to $2600 \mathrm{~mm}$. The area receives heavy snow fall during winter starting from month of November.

\section{Methods}

Both primary and secondary data were collected and compiled. Information about past GLOF events in the $\mathrm{HKH}$ region was compiled through a review of published and unpublished documents and articles. Data on glacial lake (volume, moraine dam) and flood (geomorphological features associated with the event, flood height and width,
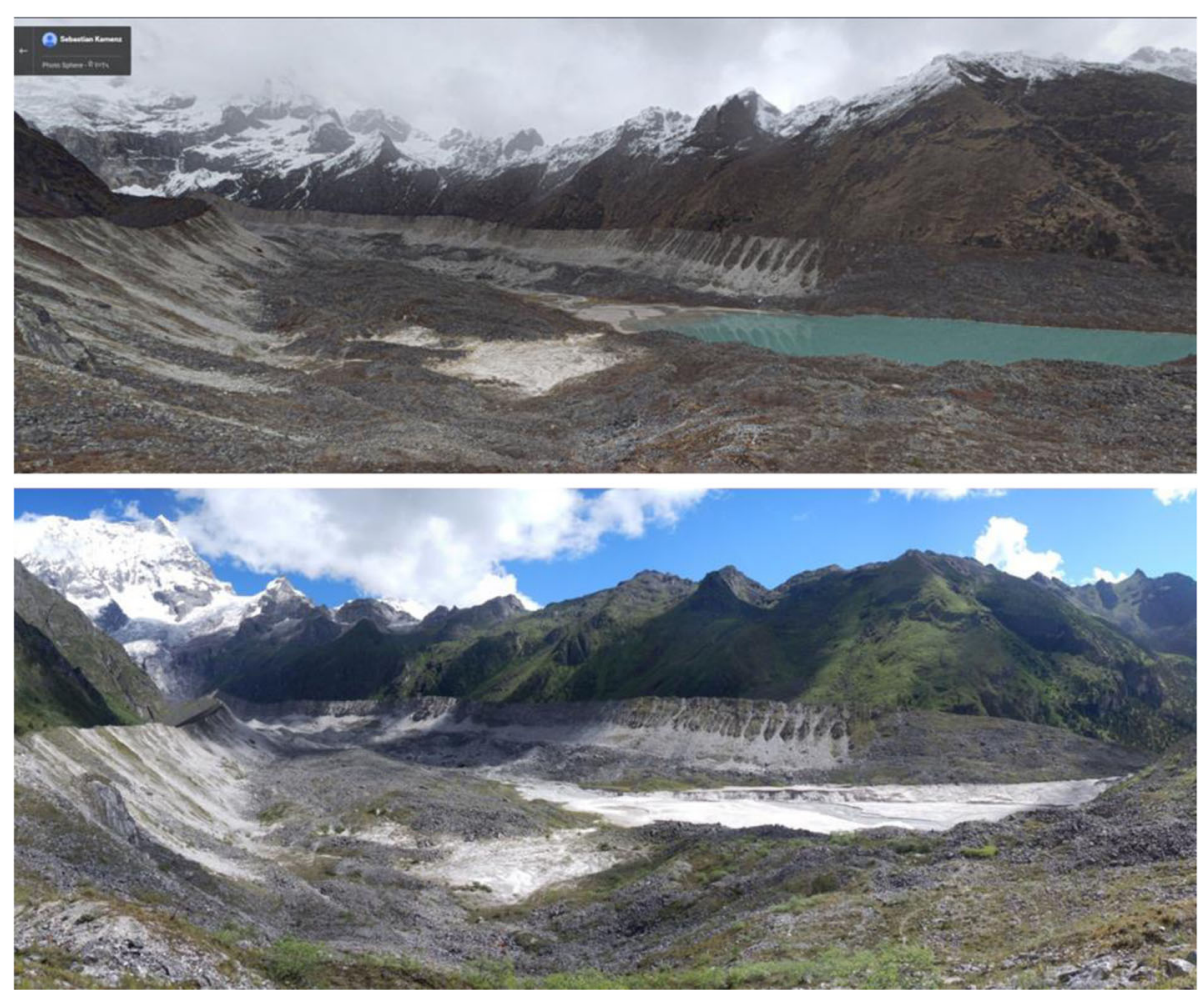

Fig. 2 Repeat photograph of Lemthang Tsho: top (pre event, May 2015) and bottom (post event, July 2015). Photo credit: Sebastian Kammer and Sharad Joshi 
downstream losses) were collected during fieldwork which was conducted after a month from the event. Flood height and width were measured based on flood marks on the river bank. The river discharge data was obtained from a station maintained by the erstwhile Department of HydroMet Services (DHMS), Royal Government of Bhutan. The DHMS has been recently renamed as the National Center for Hydrology and Meteorology (NCHM) under restructuring exercise. Detailed topographic profiles of both the lake and the moraine dam were prepared using Total Station. In addition, river channel survey, water discharge measurement, and measurement of the size of boulders deposited at different points between Lemthang Tsho and Laya were carried out. The information collected was used to develop the channel cross-section profile and estimate the peak flood discharge. The diameters of the five largest boulders deposited in the riverbed by the recent flood were measured in order to estimate the velocity using empirical equations recommended by Costa (1983). Information about damage and loss was collected through visual inspection and consultation with local people.

\section{Review}

Causes of GLOF has been discussed by many researchers (Emmer and Cochachin. 2013; Iwata et al. 2002; Yamada 1998; Vuichard and Zimmermann 1987) and there are comprehensive review on causes of GLOFs in the past (Falátková 2016; Komori et al. 2012). The published work acknowledges the role of external factor as a trigger to unleash the GLOF, thus discussions on the cause of GLOF includes two aspects: triggering mechanism and breach mechanism. The triggering mechanism which directly or indirectly causes the breach has been referred as "dynamic cause" by Emmer and Cochachin (2013). Iwata et al. (2002) in their work on causes of GLOF from moraine dam in Bhutan Himalaya has categorized trigger into in-direct trigger and direct trigger. They imply existence of cause-effect relationship amongst direct trigger, in-direct trigger, and cause of the GLOF, which is also illustrated by Emmer and Cochachin (2013) and Falátková (2016). Two indirect triggers discussed in the review are earthquake and global warming, which evoke secondary process such as ice-calving, glacier surge, failure of outlet, which eventually causes the breach (Iwata et al. 2002). The secondary trigger is termed as direct trigger as it is this that actually directly contribute in failure of the moraine dam. Earthquake can therefore be a direct trigger in an event the breach of moraine dam is caused by seismic tremors (Clauge and Evans 2000). The global warming may not be obvious as indirect trigger like earthquake, but Liu et al. (2014) did find correlation between higher GLOF of frequency and air temperature in Tibet
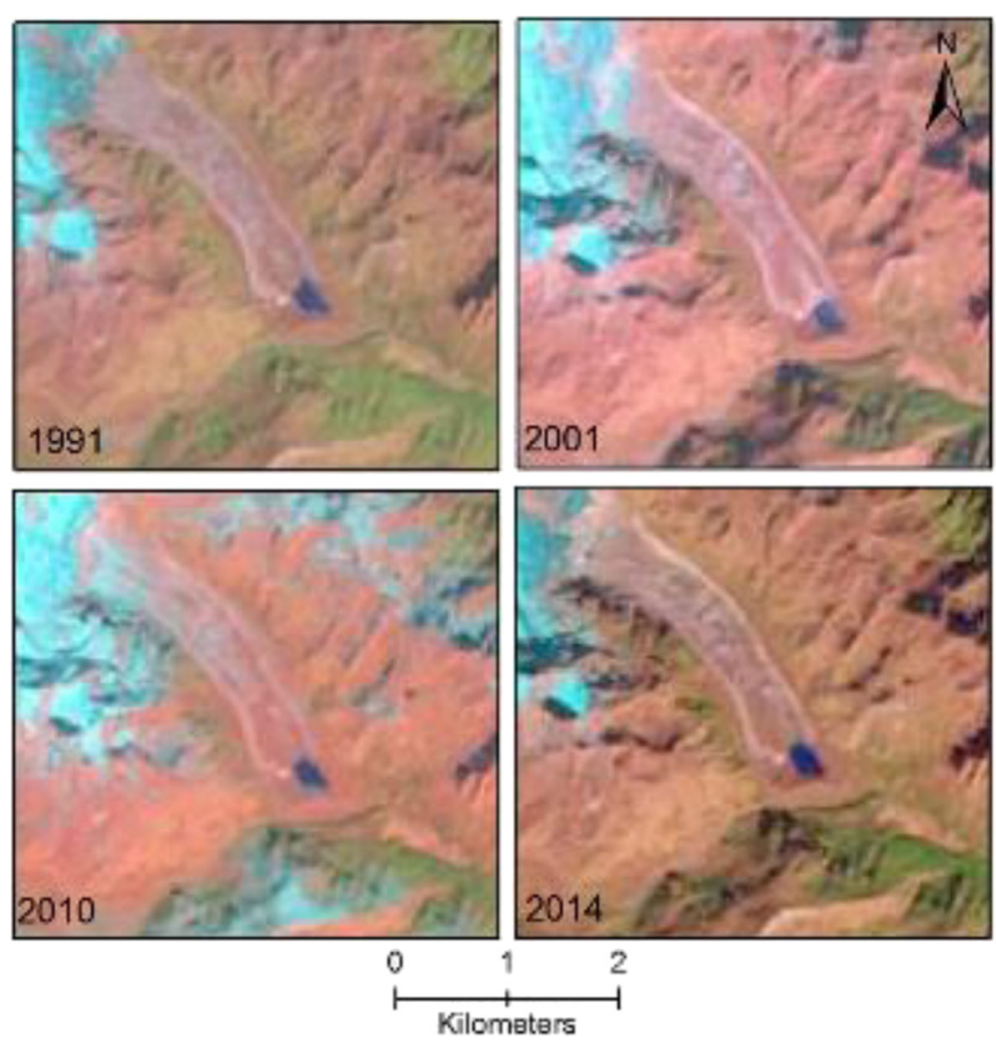

Fig. 3 Time series Landsat images showing growth progression of Lemthang Tsho 
during 1960s, 1980s. Similarly Chen et al. (2010) argued that GLOF magnitude and frequency are closely related to positive temperature trend.

There are many direct triggering mechanisms (Iwata et al. 2002) and most common of which is ice avalanche falling into a lake (Falátková 2016; Emmer and Cochachin 2013, Komori et al. 2012; Richardson and Reynolds 2000). Ice avalanche and rock fall into a lake generates a displacement (surge) wave (example Dig Tsho in 1985) which strikes the moraine wall and debilitate the dam, or overflow the dam and initiate the incision which leads to its collapse eventually (Clague and Evans 2000). Other discussed causes are rise in lake level due to enhanced inflow as compared to outflow resulting in hydrostatic pressure and moraine dam yielding to the increased pressure. The enhanced inflow can be from snow and glacier melt or from outburst in the upstream. The discussion on role of supra-glacial lakes in generating GLOF is far and few, and is being recognized lately (Komori et al. 2012), although much is still unknown. Breaching of supra-glacial in itself could result in a GLOF as in case of the Tshojo GLOF of 2009 in Bhutan (Komori et al. 2012), or it could trigger larger GLOF from glacial lake in the downstream. Merging of supra-glacial lakes could result in much larger lakes with potential for outburst as has been considered in case of Thorthormi Tsho in Bhutan. It is important that
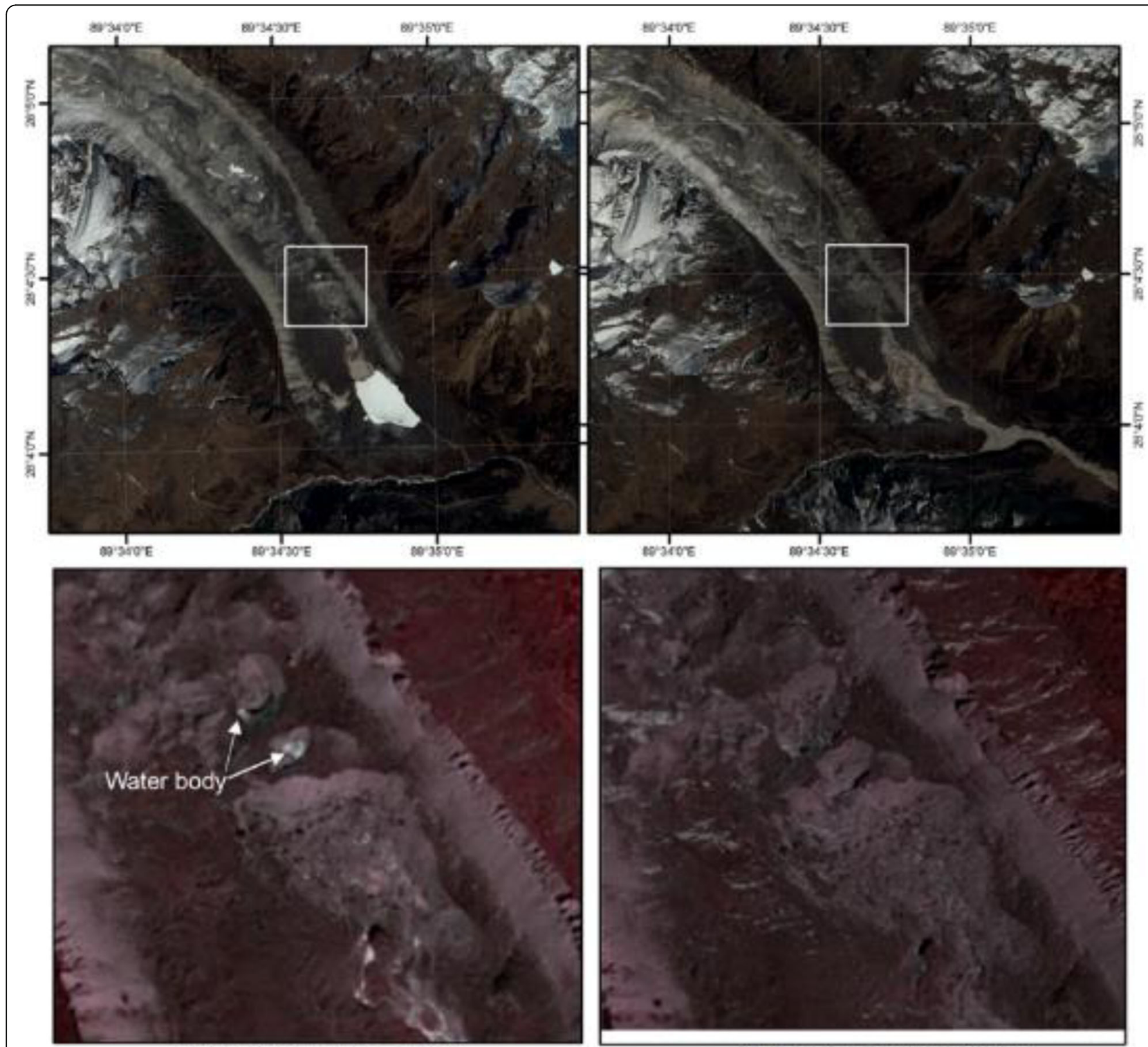

SPOT7 (11 February 2015)

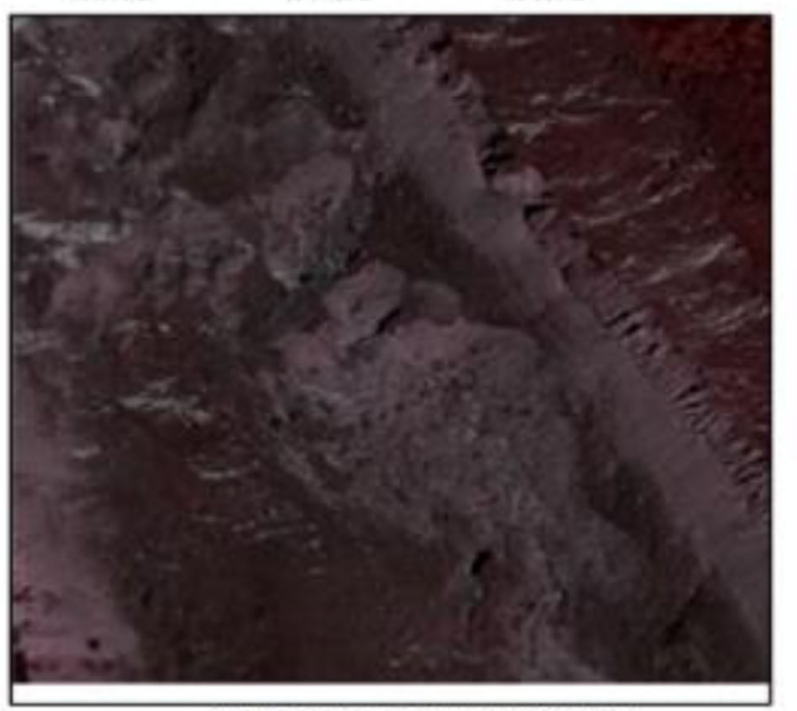

SPOT6 (16 February 2016)

Fig. 4 Pre (left) and post (right) GLOF event SPOT images of Lemthang Tsho. Bottom images clearly show the emptying of two supraglacial ponds, which ultimately resulted in the outburst 
supra-glacial lake as a trigger of GLOF is given due consideration, as it demonstrates a dynamic phenomenon (Qiao et al. 2015). The same research suggested that warmer springs seem related to the draining of some supraglacial lakes during the following seasons, due to the change in glacial drainage from unconnected to connected systems as a result of enhanced ablation during the springs. This paper will therefore deal on one of these many possibilities, and be a step towards our understanding of the role of supra-glacial lakes in generating GLOF.

Falátková 2016 assessed 38 cases of GLOF event due to breach of moraine dam across the Himalaya and reported ice avalanche falling into the lake (34\%), hydrostatic pressure as a result of the lake level rise (20\%), and melting of dead ice (14\%) as three most common causes of GLOF in Asia. Assessment of 60 historical GLOF events witnessed between 1900 and 2009 across Cordillera Blanca of Peru, the North American Cordillera, and Himalaya, found slope movement into the lake constitute $80 \%$ of the cause (Emmer and Cochachin 2013). Fifteen percentage of the events were attributed to earthquake. In the Himalaya region over two-fifth of the GLOF events resulted from "dam selfdestruction" (Emmer and Cochachin 2013), a term used to describe long-term degradation of the dam without a dynamic initiating event (Yamada 1998). It includes melting of dead ice, impact of hydrostatic pressure, and the effect of time, which contributes in destabilizing the moraine dam. In another assessment of GLOF event across the Himalaya (Richardson and Reynolds 2000) where 26 events were considered, ice avalanches into the lakes constitute over 53\%, unknown in case of over
$23 \%$ of reported events, $12 \%$ from moraine collapse due to seepage, $8 \%$ from rock avalanche into the lake, and $4 \%$ from collapse of moraines due to melting ice-cores. Similar assessment of 21 historical GLOF events in Bhutan (Komori et al. 2012) found plunging of glacier ice down into the lake (44\%), glacier calving (33\%), and ice deformation around a supraglacial lake $(10 \%)$ are top three triggering mechanism.

\section{Result}

\section{Lemthang Tsho GLOF}

The Lemthang Tsho GLOF was reported around 6:30 pm Bhutan Standard Time (BST) (GMT 6+) on 28 June 2015 by local people collecting herbs (Kuensel 2015a). The event (GLIDE No. FF-2015-000077-BTN) completely emptied the lake (Fig. 2 and 4), yet the resultant GLOF was relatively small considering the unleased water volume as well as devastation. The average depth of the lake before the outburst was $6.29 \mathrm{~m}$ with a maximum depth of $14.42 \mathrm{~m}$, which would put the estimated water volume prior to the outburst at 0.37 million $\mathrm{m}^{3}$. District authorities of two downstream districts, Punakha and Wangdiphodrong, were duly alerted, as there were concerns about additional hazard from the monsoon rains which had been heavy in the preceding weeks. The siren was manually activated around 8:45 pm (Kuensel 2015a) even before the water level $(6.66 \mathrm{~m})$ reached preset alert level $(7.5 \mathrm{~m})$ at Taktsemakhang station.

The Lemthang Tsho inventorized as Kab Tso with glacial lake ID of mo_gl_200 in inventory exercise of 2001, using topo sheet prepared using aerial photo taken in 1960s (Mool et al. 2001), indicates the existence of the

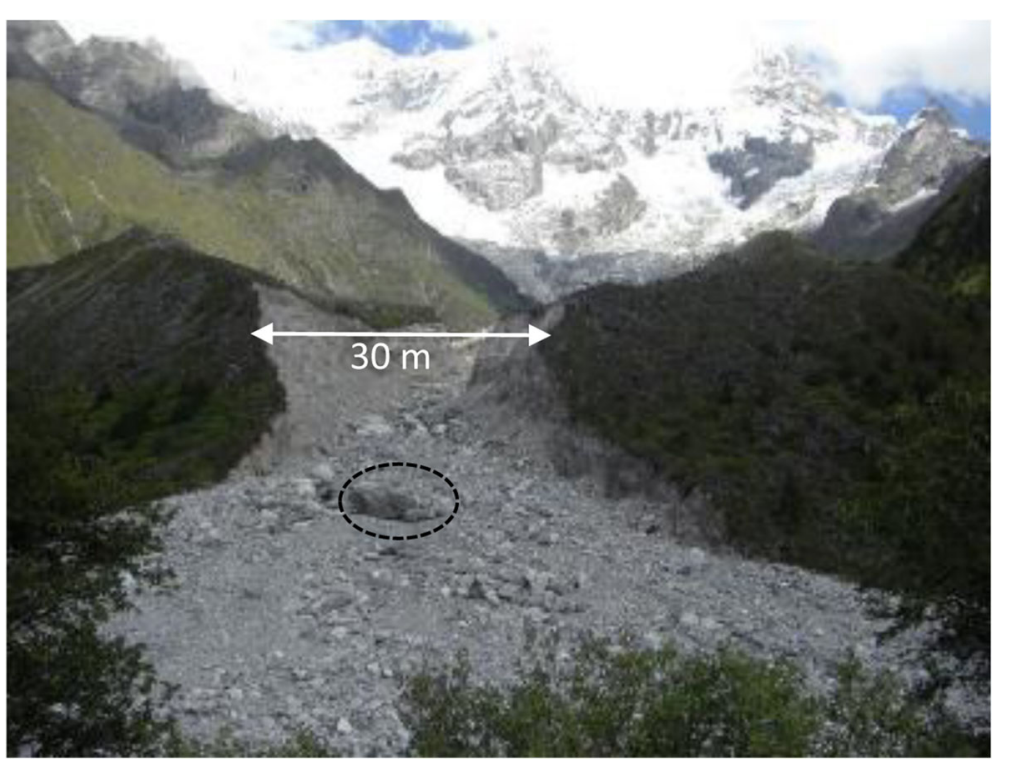

Fig. 5 Frontal view of the typical V-shaped channel morphology after the breach. A large dislodged boulder can be seen in front of the breached section 
lake over 5 decades. Due to large mother glacier at the foreground and attached to the lake with well-defined moraine dam, the Lemthang Tsho was identified as one of the 24 potentially dangerous glacial lakes (Mool et al. 2001). The lake area was $0.0521 \mathrm{~km}^{2}$ in $1960 \mathrm{~s}$ and $0.0763 \mathrm{~km}^{2}$ by 2015 , while the length increased from $285 \mathrm{~m}$ to $445 \mathrm{~m}$. With surface area increase of $0.0242 \mathrm{~km}^{2}$ in over 5 decades, Lemthang Tsho is thus characterized with slow growth rate, which is also obvious from the time series Landsat images (Fig. 3).

\section{Cause of Lemthang Tsho GLOF}

A team comprising of engineers and glaciologists were fielded within a month of the outburst to investigate the event and assess residual hazard. Field investigation revealed that two interconnected supraglacial ponds located upstream of the lake had completely drained into Lemthang Tsho which was corroborated by pre- and post-event satellite images (Fig. 4). Based on the field observation and on satellite image, the sudden subglacial draining of the supraglacial ponds is likely to have been triggered by collapse of steep ice scarp of the upper supraglacial pond. The supraglacial ponds being interconnected through a subglacial conduit, the hydrostatic pressure reconfigured the subglacial channel enhancing the flow. It is unlikely that draining of the subglacial ponds was sudden from the eyewitnesses account that breaching of Lemthang Tsho occurred several hours after the draining of supraglacial ponds (Kuensel 2015b). The possibility of a strong surge wave in case of sudden

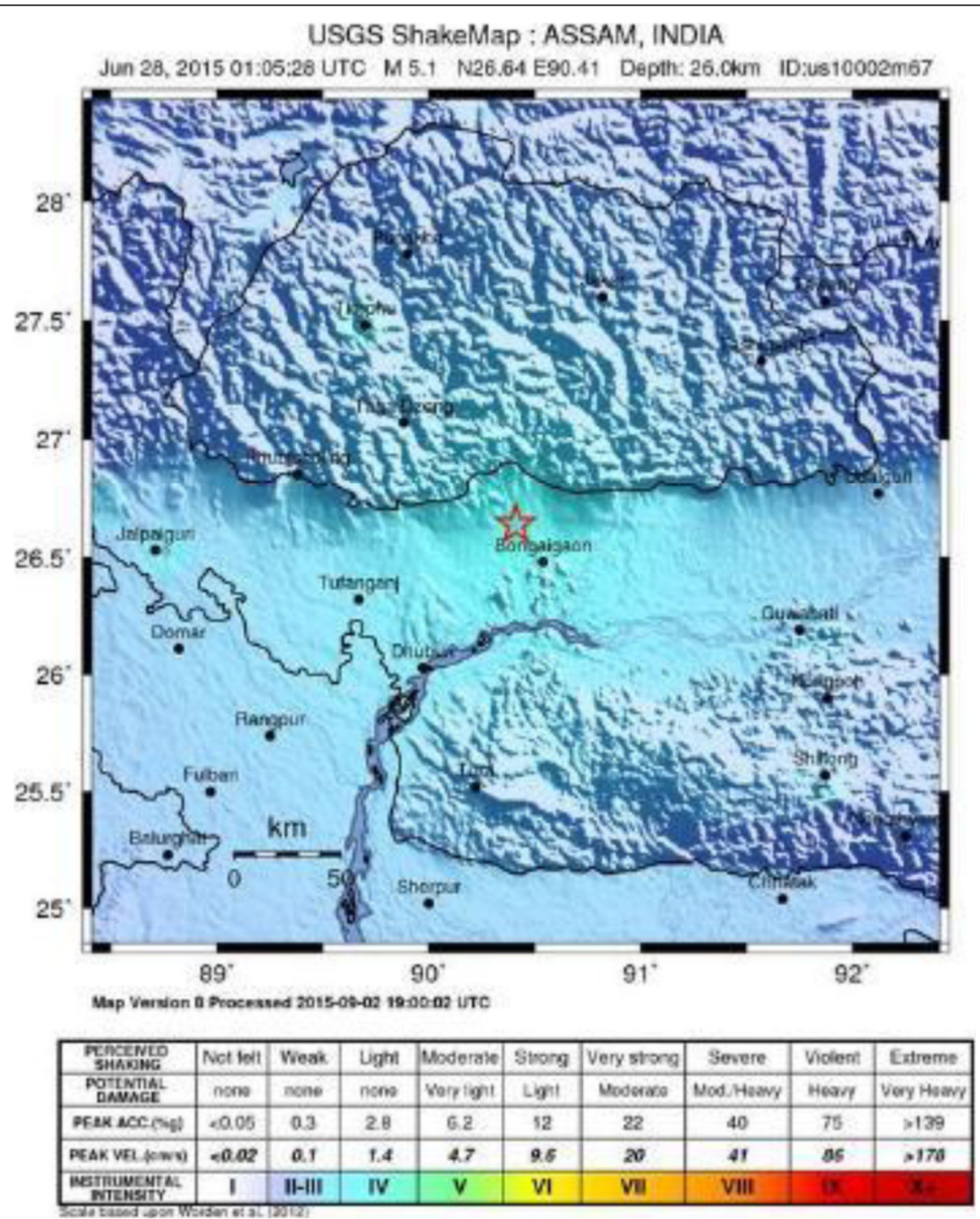

Fig. 6 Shake intensity map of M5.1 earthquake that struck Assam on the morning of 28 June 2015 (Source: USGS) 
draining of supraglacial ponds triggering the breach which often happens in quick succession is ruled out. Alternatively likely scenario involves a gradual rise in the lake level as the supraglacial ponds emptied into Lemthang Tsho and subsequent buildup of hydrostatic pressure which justifies eye witness account of time laps between these two events. As has been discussed in the review section, the increase in outflow as a result of rise in lake water and buildup of hydrostatic pressure increased the outflow discharge and subsequently increased erosion thereby widening the outlet. The dislodgement of the $10 \mathrm{~m} \times 4 \mathrm{~m} \times 3 \mathrm{~m}$ boulder (Fig. 5) as a result of increased erosion is considered the moment of breach, which as per eyewitness report happened about $5 \mathrm{pm}$ BST. Sequencing the events based on the eyewitness account and likely scenario, the breach of supraglacial is likely to have happened around $3 \mathrm{pm}$ BST. Two flood peaks an hour apart at 7:30 pm and 8:30 pm at Laya station indicates breaching to have occurred in two phases, at (Kuensel 2015a). The breach created a $30 \mathrm{~m}$ wide Vshaped outlet morphology (Fig. 2), typical of failure of moraine dam. This is not the first time that a supraglacial breach induced a GLOF in Bhutan. In the early hours of 29 April 2009, an outburst event at the supraglacial lakes on the Tshojo glacier, in the headwaters of Pho Chu had resulted in a GLOF (Komori et al. 2012).

The question of what triggered the slump of the nearvertical wall of the supraglacial ponds has drawn attention to two external events that took place around the same time. Gasa had recorded $3.75 \mathrm{~mm}$ of rain on 27 June and received heavy rain that night and on the morning of 28 June 2015 (Kuensel 2015a). The other suspect is the magnitude 5.1 earthquake with its epi-centre in the Indian state of Assam Fig. 6, $187 \mathrm{~km}$ southeast of Lemthang

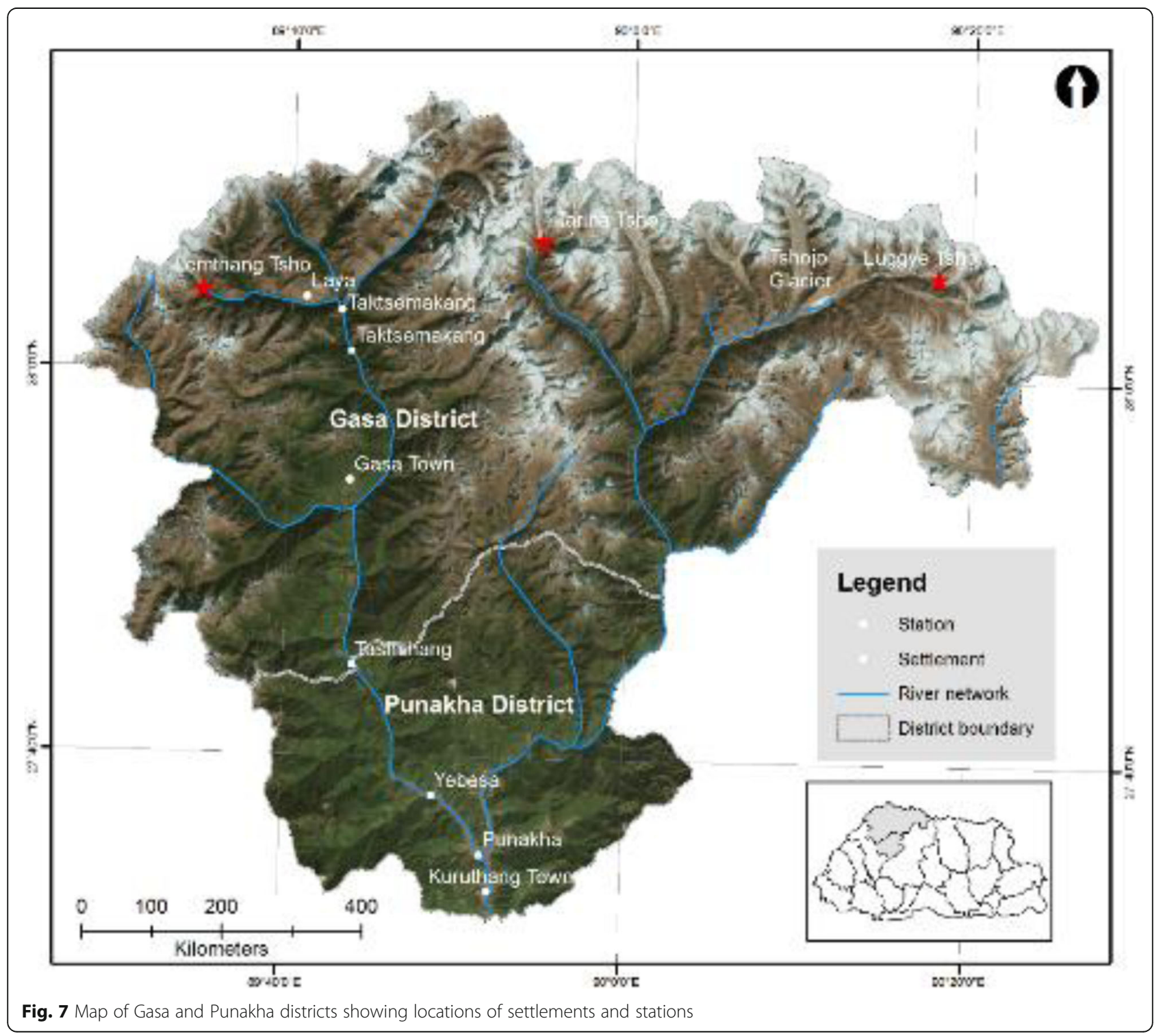


Table 1 Estimated peak discharge of GLOF and the distance to downstream sites where the GLOF events caused damages

\begin{tabular}{|c|c|c|c|c|c|c|c|}
\hline Name of Lake & Country & Date of outburst & $\begin{array}{l}\text { Lake volume } \\
\left(\text { million } \mathrm{m}^{3}\right)\end{array}$ & $\begin{array}{l}\text { Peak discharge } \\
\left(\mathrm{m}^{3} / \mathrm{s}\right)\end{array}$ & $\begin{array}{l}\text { Velocity } \\
(\mathrm{m} / \mathrm{s})\end{array}$ & $\begin{array}{l}\text { Downstream } \\
\text { impact (km) }\end{array}$ & Sources \\
\hline Qubixiama-Cho & China & 10 June 1940 & & 3690 & 7.7 & & LIGG, 1988 \\
\hline Sangwang-Cho & China & 16 July 1954 & 300 & 10,000 & & 200 & Xin et al., 2013 \\
\hline Damenhai-Cho & China & 26 September 1964 & & 2000 & 10 & & Wu et al., 2005; Ding and Liu, 1992 \\
\hline Longdaco & China & August 1964 & & 1000 & & & Chen et al., 2013 \\
\hline Gelhaipuco & China & September 1964 & & 4500 & & & Chen et al., 2013 \\
\hline Zhangzangbo & China & 11 July 1981 & 19 & 15,920 & $7-17.9$ & 60 & $\mathrm{Xu}, \mathrm{D}, 1988$ \\
\hline Ganxico (Mitui-Cho) & China & 14 July 1988 & & 1270 & & & Liu et al., 2014 \\
\hline Nare & Nepal & 3 September 1977 & 4.9 & $830-1100$ & & 90 & Buchroter et al., 1982 \\
\hline Dig Tsho & Nepal & 4 August 1985 & $6-10(8)$ & $1600-2000$ & & 90 & Viuchard and Zimmerman, 1987 \\
\hline Tam Pokhari & Nepal & 3 September 1988 & & 10,000 & $5-10$ & 66 & $\begin{array}{l}\text { OSTI AND Egashira, 2009; Dwivedi } \\
\text { et al., } 2000\end{array}$ \\
\hline Luggye Tsho & Bhutan & 7 October 1994 & 48 & $>2500$ & & 200 & Richardson and Reynolds, 2000 \\
\hline
\end{tabular}

Tsho (Fig. 1) (https://earthquake.usgs.gov/archive/product/losspager/us10002m67/us/1441220705024/onepager.pdf). The earthquake with hypocenter at depth of $27 \mathrm{~km}$ struck at 7:10 am BST on 28 June 2015. Tremor was reported in print media to have felt as far as Thimphu and Bumthang districts but there were no reports from Gasa district (Fig. 1). On the shake intensity map sourced from USGS (Fig. 4), Lemthang Tsho area has been classified under 'weak shaking' (Instrumental Intensity - II). Although it is unlikely that the earthquake to have triggered the slump of the near-vertical wall of the supraglacial ponds, its role in conjunction with heavy rainfall could not be completely ruled out in absence of eyewitness accounts and firsthand data from in-situ stations.

\section{GLOF characteristic}

As mentioned above, the flood propagated in two phases, an hour apart. Flood wave took $1 \mathrm{~h} 30 \mathrm{~min}$ to reach Taktsemakhang station at Laya (Fig. 7). Further down flood took $1 \mathrm{~h}$ and $45 \mathrm{~min}$ and $2 \mathrm{~h}$ and $45 \mathrm{~min}$ to travel from Taktsemakhang to Trashithang and Yabesa stations respectively, a distance of $45 \mathrm{~km}$ and $75 \mathrm{~km}$ (Kuensel 2015a). Therefore flood wave is estimated to have travelled with average velocity ranging from 7.14$7.57 \mathrm{~m} / \mathrm{s}$, which is higher than Luggye Tsho GLOF with estimated velocity of $3 \mathrm{~m} / \mathrm{s}$ (Watanabe and Rothacher 1996) (Table 1). Further downstream, maximum discharge of $1198 \mathrm{~m}^{3} / \mathrm{s}$ was recorded at Punatsangchu Hydropower project site (Kuensel 2015a) (Fig. 7). Figure
8 is a longitudinal profile of Mo Chu from Lemthang Tsho to Punakha Dzong, a seat of district administration (Fig. 1).

Reconstruction of peak discharge was carried out using average intermediate diameters of the five largest boulders measured at different downstream points, using river width and depth information obtained from the field. For this we used empirical equations recommended by Strand (1977) and Costa (1983) to estimate mean velocity (Eqs. $1 \& 2$ ). The estimated discharge is found to range from 426 to $558 \mathrm{~m}^{3} / \mathrm{s}$ near Laya and $1253-1562 \mathrm{~m}^{3} / \mathrm{s}$ (Table 2) upstream near the confluence of the two rivers, where a debris flow fan was formed (Point No. 2 in Fig. 9). It is likely that the flow was obstructed by the tributary, which resulted in deposition of materials (Strand, 1977; Costa, 1983).

$$
\begin{aligned}
& \bar{v}=0.18 d^{0.487} \\
& V_{b}=0.51 d^{0.5}
\end{aligned}
$$

\section{Impact}

Downstream losses from the flood were concentrated in the stretch between the Lemthang Tsho and Kohina village (Fig. 7), a distance of $30 \mathrm{~km}$ downstream from the source. As per the Laya Gewog Administration, a total of four bridges were washed and one acre of agricultural land damaged. About $1 \mathrm{~km}$ stretch of a trail was damaged due to landslides triggered at several places within

\begin{tabular}{|c|c|c|c|c|c|c|}
\hline Site & Name & Width (m) & Average depth (m) & Average boulder diameter (mm) & Velocity (m/s) & Discharge $\left(\mathrm{m}^{3} / \mathrm{s}\right.$ \\
\hline 1 & Near confluence (5.5 km downstream) & 45.7 & 3.15 & 2880 & $8.71-10.85$ & $1253.79-1562.20$ \\
\hline 2 & Laya (9 km downstream) & 25 & 3.2 & 1190 & $5.66-6.98$ & $453.06-558.05$ \\
\hline 3 & Laya (9.5km downstream) & 25 & 3.8 & 730 & $4.46-5.45$ & $424.07-519.04$ \\
\hline
\end{tabular}

Table 2 Summary of estimated discharge at three downstream sites 


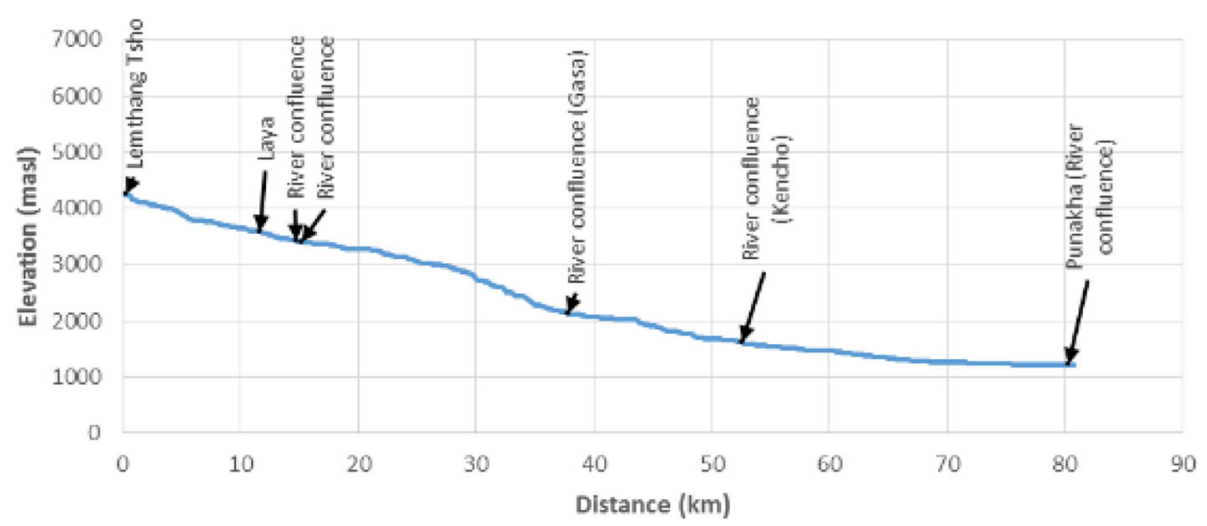

Fig. 8 Longitudinal profile of Mo Chu downstream from Lemthang Tsho to Punakha Dzong

the stretch as a result of toe cutting by flood on a hilly slope. Four horses and timber piled along the riverbed were swept away by the GLOF. The summary of direct loss due to the flood event is provided in Table 3.

Erosion and sedimentation is a major secondary hazard associated with GLOF and can have severe and prolonged socio-ecological impact (Vilímek et al. 2015; Higaki and Sato 2012). The GLOF in the past have converted fertile grazing/agricultural land into a field of sand and boulders, adversely affecting the livelihoods of the local people. The extent of erosion and sedimentation in this event was limited and was confined up to $25 \mathrm{~km}$ downstream from the lake (Fig. 7). As the outburst dislodges and washes away moraine materials a debris in the form of a fan in front of the end moraine is clearly visible in the satellite image (Fig. 4 and 5). Similarly, sand and boulder debris were found deposited further downstream (Point No. 2 in Fig. 9) where loss of gradient has decreased carrying capacity of the flood. As usual there were scouring at places along the river bank

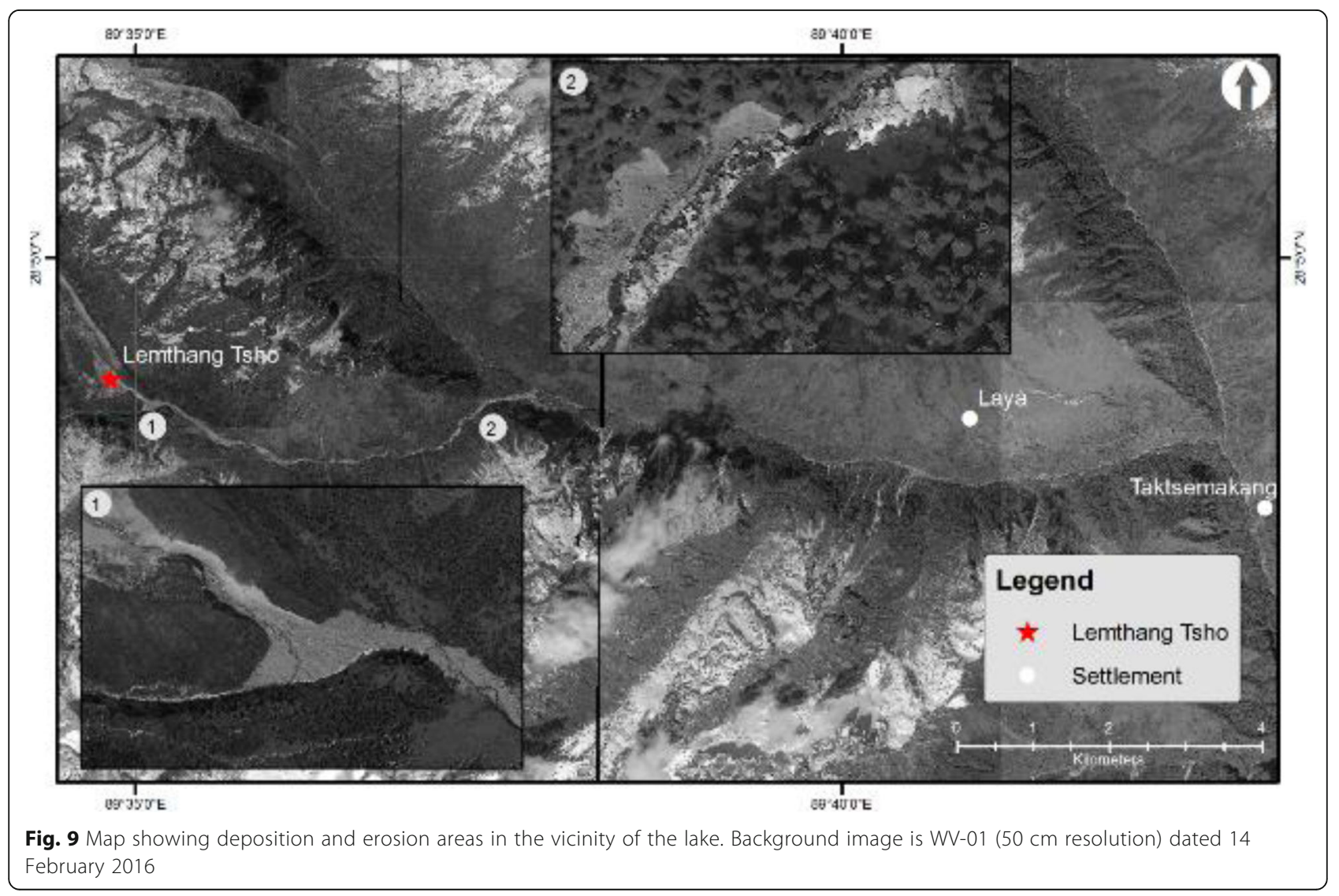


Table 3 Direct loss due to the GLOF

\begin{tabular}{llll}
\hline Damages & Quantity & $\begin{array}{l}\text { Estimated loss } \\
\text { (Nu. Million) }\end{array}$ & Remarks \\
\hline Bridges washed away & 4 & 0.976 & $\begin{array}{l}\text { Timber } \\
\text { cantilever }\end{array}$ \\
Land affected & 1 acre & \\
Horses lost & $\begin{array}{l}4(3 \text { phochen } \\
\text { and 1 dreng) }\end{array}$ & \\
Timber washed away & 148 pieces & & \\
Trail damaged & $1 \mathrm{~km}$ & & \\
\hline
\end{tabular}

Source: Laya Gewog Administration and Observation

up to $25 \mathrm{~km}$ downstream. Since the river runs through a deep gorge beyond $25 \mathrm{~km}$ between Kohina and Gasa $(25 \mathrm{~km}-39 \mathrm{~km})$, the $14 \mathrm{~km}$ stretch is inaccessible. There was no impact noticed further down at Tashithang (about $50 \mathrm{~km}$ downstream). Given the terrain is steep and barren, and climatic condition harsh, it will be a while before the erosion process ceases and stability regained. This will have prolonged impact in the downstream due to increased sediment transport sourced from such erosional sites. Thus the impact could be long drawn out process.

\section{Discussion and conclusion}

The threat of GLOF still looms large in the Himalaya due to climate change and regular seismic activities, and risk management interventions should be based on sound understanding of the processes involved, including the cause. Among many different causes discussed earlier, the avalanche (ice and rock) triggering the surge wave and causing breach seems to be the most common cause of GLOF in the Himalaya. The role of supraglacial lakes in triggering GLOF has been largely left from the discussion, and is not considered a criteria to identify critical glacial lakes. The Lemthang Tsho GLOF and Tshojo GLOF (Komori et al. 2012) cases highlights that supraglacial ponds can trigger GLOF, and needs to be considered while doing hazard/risk assessment. The role of earthquake in triggering Lemthang Tsho GLOF event is difficult to confirm or discount in absence of firsthand information, but seems unlikely due to weak intensity of shaking. Strasser et al. (2008) expressed that role earthquake in triggering GLOF in general is difficult due to vary many ways it can manifests, some of which are sub-glacial phenomenon. As in case of lake Parón, inhibited outflow due to an earthquake resulted in rise in lake level which ultimately caused GLOF, but well past the earthquake event (Lliboutry et al. 1977). The two days of incessant rainfall is likely to have destabilized the steep scarp due to relatively warmer raindrops melts the glacier, and is more likely have played a role in creating Lemthang Tsho GLOF. However, the region being seismically very active zone, the role of earthquake as a trigger of GLOF cannot be overlooked.
The Lemthang Tsho GLOF event by all measure was a small event accounting for relatively minimum impact in terms of direct damage. However, indirect damage such as impact on livelihood due to loss of grazing land to debris, and prolonged hillslope erosion is far reaching. The event despite its' small size reminds us of the GLOF risk that $\mathrm{HKH}$ countries faces, and to take the threat seriously.

There is a need to relook into existing list of critical glacial lakes and update it, as the existing list was prepared over a decade ago using topo maps some of which prepared based on aerial photo of 1960 s' $^{\prime}$ (Mool et al. 2001; Ives et al. 2010). Since then glaciers and glacial lakes must have undergone lot of changes thus warranting a revision. Total of 24 glacial lakes were identified as the critical glacial lakes based on the condition of lakes, dams, associated mother glaciers, and topographic features around the lakes and glaciers. Addition of Thorthormi glacial lakes had brought the figure to 25 (WWF 2009). The Thorthormi Tsho was categorized as dangerous lake based on unstable moraine condition, seepage, and likelihood of developing into a large lake by Iwata et al., 2002 also. Two other critical glacial lakes: Latshokarp (Mo_gl_201) and Langdo Latshokarp (Mo_gl_202) among 25 are located in adjacent valley to Lemthang Tsho, which the team verified in the field. Having found that that they do not pose immediate GLOF threat considering the size, moraine stability, mother glacier, and surrounding geomorphology, risk level is downgraded (Kuensel 2015b). The updated figure of critical glacial lakes in Bhutan, having downgraded the risk level of 3 glacial lakes (including Lemthang Tsho) is 22. The Lemthang Tsho GLOF highlights the role of supraglacial lake in triggering GLOF event and its' importance as a criteria for updating the list of critical glacial lakes. Finally, the issue of GLOF being a trans-boundary concern, cross learning across countries in the region and beyond needs to be promoted. There is benefit in addressing the common threat collectively.

\footnotetext{
Acknowledgements

The study is jointly supported by United States Agency for International Development (USAID), National Aeronautics and Space Administration (NASA), and Norwegian Ministry of Foreign Affairs, and Royal Government of Bhutan (RGOB). We extend our sincere appreciation to these organizations. The team would like to thank different agencies of the RGOB in facilitating the field expedition, and the administration of Gasa District deserves a special mention for extending all possible assistance during the expedition. The team is greatly indebted to ICIMOD colleagues for support and guidance. Thanks to two anonymous reviewers who helped improve this manuscript to present level. This study was partially supported by the core funds of ICIMOD, which received contributions from the governments of Afghanistan, Australia, Austria, Bangladesh, Bhutan, China, India, Myanmar, Nepal, Norway, Pakistan, Switzerland, and the United Kingdom.

The views expressed in this paper are those of the author(s). They are not necessarily those of ICIMOD and do not imply the expression of any opinion whatsoever on the part of ICIMOD concerning the legal status of any country, territory, city or area, or of the delineation of its frontiers or boundaries, and nor do they imply the endorsement of any product.
} 


\section{Authors' contributions}

DRG performed image analysis and finalized the paper, NRK and SRB collected the field data and drafted the manuscript outline, KT, SJ, PT, LKC, YL, TP collected field data and provided comments on manuscript. All authors read and approved the final manuscript.

\section{Competing interests}

The authors declare that they have no competing interests.

\section{Publisher's Note}

Springer Nature remains neutral with regard to jurisdictional claims in published maps and institutional affiliations

\section{Author details}

IInternational Centre for Integrated Mountain Development, Khumaltar, Lalitpur, Nepal. ${ }^{2}$ Tribhuvan University, Kathmandu, Nepal. ${ }^{3}$ National Center for Hydrology and Meteorology, Royal Government of Bhutan, Thimphu, Bhutan. ${ }^{4}$ Department of Geology and Mines, Royal Government of Bhutan, Thimphu, Bhutan. ${ }^{5}$ Department of Disaster Management, Royal Government of Bhutan, Thimphu, Bhutan. ${ }^{6}$ District Administration, Sarpang District, Royal Government of Bhutan, Thimphu, Bhutan.

\section{Received: 23 January 2017 Accepted: 23 May 2017}

Published online: 02 June 2017

\section{References}

Ashraf, A., R. Naz, and R. Roohi. 2012. Glacial lake outburst flood hazards in Hindukush, Karakoram and Himalayan ranges of Pakistan: Implications and risk analysis. Geomatics, Nat. Hazards Risk 3: 113-132 http://dx.doi.org/10. 1080/19475705.2011.615344.

Buchroithner MF, Jentsch G, Wanivenhaus B. 1982. Monitoring of Recent Geological Events in the Khumbu Area (Himalaya, Nepal) by Digita Processing of Landsat MSS Data. Rock Mechanics 15:181-197.

Carey, M., C. Huggel, J. Bury, C. Portocarrero, and W. Haeberli. 2012. An integrated socio-environmental framework for glacier hazard management and climate change adaptation: Lessons from Lake 513, Cordillera Blanca, Peru. Climatic Change 112: 733-767. doi:10.1007/s10584-011-0249-8.

Chen, N. S., G.S. Hu, W. Deng, N. Khanal, Y. Zhu, and D. Han. 2013. On the water hazards in the trans boundary Kosi River basin. Natural Hazards and Earth System Sciences. 13(3): 795-808.

Chen, Y., C. Xu, W. Li, and J. Liu. 2010. Response of glacial lake outburst floods to climate change in the Yarkant river basin on northern slope of Karakoram mountains, China. Quaternary International 226: 75-81. doi:10.1016/j.quaint. 2010.01.003.

Clauge, J.J., and S.G. Evans. 2000. A review of catastrophic drainage of morainedammed lakes in British Columbia. Quaternary Science Reviews 19: 1763-1783.

Cook, K., C. Andermann, F. Gimbert, N. Hovius, and B. Adhakari. 2017. Impacts of the 2016 outburst flood on the Bhote Koshi River valley, central Nepal. Geophysical Research Abstracts 19: EGU2017-10570-1.

Costa, J.E. 1983. Paleohydraulic reconstruction of flash-flood peaks from boulder deposits in the Colorado front range. Geological Society of America Bulletin 94: $986-1004$.

Cramer, W., Yohe, G.W., Auffhammer, M., Huggel, C., Molau, U., da Silva Dias, M.A. F., Solow, A., Stone, D.A., and Tibig, L. 2014. Detection and attribution of observed impacts. In: Climate change 2014: Impacts, adaptation, and vulnerability. Part a: Global and Sectoral aspects. Contribution of Working group II to the fifth assessment report of the Intergovernmental Panel on climate change [Field, C.B., V.R. Barros, D.J. Dokken, K.J. Mach, M.D. Mastrandrea, T.E. Bilir, M. Chatterjee, K.L. Ebi, Y.O. Estrada, R.C. Genova, B. Girma, E.S. Kissel, A.N. Levy, S. MacCracken, P.R. Mastrandrea, and L.L. White (eds.)]. Cambridge University Press, Cambridge, United Kingdom and New York, NY, USA, pp. 979-1037.

Daoming, X., and F. Qinghua. 1994. Dangerous glacier lakes and their outburst features in the Tibetan Himalayas. Bulletin of Glacier Research 12: 1-8.

Ding, Y., and J. Liu. 1992. Glacier lake outburst flood disasters in China. Annals of Glaciology 16: 180-184.

Dorji, U., J.E. Olesen, P.K. Bocher, and M.S. Seidenkrantz. 2016. Spatial variation of temperature and precipitation in Bhutan and links to vegetation and land cover. Mountain Research and Development 36 (1): 66-79.
Dwivedi, S.K., M.D. Acharya, and R. Simard. 2000. The tamp Pokhari glacier lake outburst flood of 3 September 1988. Journal of Nepal Geological Society 22: 539-546.

Emmer, A., and A. Cochachin. 2013. The causes and mechanisms of morainedammed lake failures in the Cordillera Blanca, north American Cordillera, and Himalayas. AUC GEOGRAPHICA 48 (2): 5-15.

Falátková, K. 2016. Temporal analysis of GLOFs in high-mountain regions of Asia and assessment of their causes. AUC GEOGRAPHICA 51 (2): 145-154.

Field, C.B., V.R. Barros, D.J. Dokken, K.J. Mach, M.D. Mastrandrea, T.E. Bilir, M. Chatterjee, K.L. Ebi, Y.O. Estrada, R.C. Genova, B. Girma, E.S. Kissel, A.N. Levy, S. MacCracken, P.R. Mastrandrea, L.L. White, and editors. 2014. Climate change 2014: Impacts, adaptation, and vulnerability. Part a: Global and Sectoral aspects. Contribution of Working group II to the fifth assessment report of the Intergovernmental Panel on climate change. Cambridge, UK, and New York, NY: Cambridge University Press.

Field, C.B., V. Barros, T.F. Stocker, D. Qin, D.J. Dokken, K.L. Ebi, M.D. Mastrandrea, K. J. Mach, G.K. Plattner, S.K. Allen, M. Tignor, and P.M. Midgley. 2012. Managing the risks of extreme events and disasters to advance climate change adaptation. A Special Report of Working Groups I and II of the Intergovernmental Panel on Climate Change. Cambridge, UK, and New York, NY: Cambridge University Press.

Gardelle, J., Y. Arnaud, and E. Berthier. 2011. Contrasted evolution of glacial lakes along the Hindu Kush Himalaya mountain range between 1990 and 2009. Global and Planetary Change 75 (1-2): 47-55.

Haeberli, W. 1983. Frequency and characteristics of glacier floods in the Swiss alps. Annals of Glaciology 4: 85-90.

Haeberli, W., A. Kääb, D.V. Mühll, and P. Teysseire. 2001. Prevention of outburst floods from periglacial lakes at Grubengletscher, Valais, Swiss alps. Journal of Glaciology 47 (156): 111-122.

Hewitt, K. 1982. Natural dams and outburst floods of the Karakoram Himalaya. In Hydrological aspects of alpine and High Mountain areas. Proceedings of the Exeter symposium, July 1982, IAHS Publication, ed. J.W. Glen, vol. 138, 259-269. Wallingford, United Kingdom: International Association of Hydrological Sciences.

Higaki, D., and G. Sato. 2012. Erosion and sedimentation caused by glacial Lake outburst floods in the Nepal and Bhutan Himalayas. Global Environmental Research 16: 71-76.

Ives, J.D. 1986. Glacial Lake outburst floods and risk engineering in the Himalaya: A review of the Langmoche Disaster, Khumbu Himal, 4 August 1985. Occasional paper 5. Kathmandu, Nepal: International Centre for Integrated Mountain Development.

Ives, J.D., R.B. Shrestha, and P.K. Mool. 2010. Formation of glacial lakes in the Hindu Kush-Himalayas and GLOF risk assessment. Kathmandu: ICIMOD.

Iwata, S., Y. Ageta, N. Naito, A. Sakai, C. Narama, and Karma. 2002. Glacial Lakes and their outburst flood assessment in the Bhutan Himalaya. Global Environmental Research 6: 3-18.

Jacquet, J., S. McCoy, D. McGrath, D. Nimick, M. Fahey, J. O'kuinghttons, B. Friesen, and J. Leidich. 2017. Hydrologic and geomorphic changes resulting from episodic glacial lake outburst floods: Rio Colonia, Patagonia, Chile. Geophysical Research Letters 44 (2): 854-864

Kathmandupost. http://kathmandupost.ekantipur.com/news/2017-01-22/glof-intibet-caused-last-years-bhote-koshi-flood.html. Accessed on 5 April 2017.

Khanal, N.R., K. Banskota, A.B. Shrestha, P. Mool, and C.P. Acharya. 2013. Bhote Koshi/sun Koshi River, Nepal: Potential GLOF risk assessment and management. In Case studies on flash flood risk Management in the Himalayas: In support of specific flash flood policies, ed. A.B. Shrestha and S.R. Bajracharya, 12-17. Kathmandu, Nepal: International Centre for Integrated Mountain Development.

Komori, J., T. Koike, T. Yamanokuchi, and P. Tshering. 2012. Glacial lake outburst events in the Bhutan Himalayas. Global Environmental Research 16: 59-70.

Kuensel, 30 June 2015a. http://www.kuenselonline.com/assessment-on-lakeoutburst-begins/. Accessed on 8 February 2017.

Kuensel, 14 August 2015b. http://www.kuenselonline.com/experts-findearthquake-did-not-cause-glof/. Accessed on 8 February 2017.

LIGG; WECS; NEA (1988) Report on first expedition to glacier and glaciers lakes in the Pumqu (Arun). and Poiqu (Bhote-Sun Kosi). river basin, Xizang (Tibet), China: Sino-Nepalese investigation of glacial lake outburst floods in the. Himalaya. Beijing: Science Press.

Liu, J.J., Z.L. Cheng, and Y. Li. 2014. The 1988 glacial lake outburst flood in Guangxieco lake, Tibet. China. Nat. Hazards Earth Syst. Sci. 14: 3065-3075. doi:10.5194/nhess-14-3065-2014. 
Lliboutry, L., B.A. Morales, A. Pautre, and B. Schneider. 1977. Glaciological problems set by the control of dangerous lakes in Cordillera Blanca, Peru. I. Historical failures of moranic dams, their causes and prevention. Journal of Glaciology 18: 239-254.

Long, S., N. McQuarrie, T. Tobgay, D. Grujic, and L. Hollister. 2011. Geologic map of Bhutan. Journal of Maps 7 (1): 184-192.

Luo, D.F., and J.Z. Mao. 1995. Mountain hazards and countermeasures along southern Sichuan- Xizang highway (in Xizang), 105-108. Beijing: Science Press.

Mool, P.K, Wangda, D., Bajracharya, S.R., Kunzang, K., Gurung, D.R., and Joshi, S.P. 2001. Inventory of glaciers, glacial lakes, and glacial lake outburst floods: Monitoring and early warning systems in the Hindu Kush-Himalayan region - Bhutan. Kathmandu: ICIMOD. ISBN 929115362 1. pp 127.

Narama, C., M. Duishonakunov, A. Kääb, M. Daiyrov, and K. Abdrakhmatov. 2010 The 24 July 2008 outburst flood at the western Zyndan glacier lake and recent regional changes in glacier lakes of the Teskey ala-too range, Tien Shan, Kyrgyzstan. Natural Hazards and Earth System Sciences 10 (4): 647-659.

Osti, R., and S. Egashira. 2009. Hydrodynamic characteristics of the tam Pokhari glacial Lake outburst flood in the Mt. Everest region, Nepal. Hydrological Processes 23: 2943-2955. doi:10.1002/hyp.7405.

Qiao, L., C. Mayer, and S. Liu. 2015. Distribution and interannual variability of supraglacial lakes on debris-covered glaciers in the khan Tengri-Tumor Mountains, Central Asia. Environmental Research Letters 10 (1): 014014. doi:10. 1088/1748-9326/10/1/014014.

Riaz, S., A. Ali, and M.N. Baig. 2014. Increasing risk of glacial lake outburst floods as a consequence of climate change in the Himalayan region. Journal of Disaster Risk Studies 6 (1): 1-7. doi:10.4102/ jamba.v6i1.110.

Richardson, S.D., and J.M. Reynolds. 2000. An overview of glacial hazards in the Himalayas. Quaternary International 65 (66): 31-47.

Shrestha, A.B., M. Eriksson, P. Mool, P. Ghimire, B. Mishra, and N.R. Khanal. 2010. Glacial lake outburst flood risk assessment of sun Koshi basin, Nepal. Geomatics, Natural Hazards and Risk 1 (2): 157-169. doi:10.1080/ 19475701003668968.

Strand, R.I. 1977. Design of small dams. Reservoir sedimentation, 767-796. U.S Bureau of Reclamation, Water Resources Technical Publications.

Strasser, M., C. Schindler, and F.S. Anselmetti. 2008. Late Pleistocene earthquaketriggered moraine dam failure and outburst of Lake Zurich, Switzerland. Journal of Geophysical Research 113: 1-16. doi:10.1029/2007JF000802.

Vilímek, V., J. Klimeš, A. Emmer, and M. Benešová. 2015. Geomorphologic impacts of the glacial lake outburst flood from lake no. 513 (Peru). Environmental Earth Sciences. 73 (9): 5233-5244. doi:10.1007/s12665-014-3768-6.

Vuichard, D., and M. Zimmermann. 1987. The 1985 catastrophic drainage of a moraine-dammed Lake, Khumbu Himal, Nepal: Cause and consequences. Mountain Research and Development 7 (2): 91-110.

Watanabe, T., and D. Rothacher. 1996. The 1994 Lugge Tsho glacial Lake outburst flood, Bhutan Himalaya. Mountain Research and Development 16 (1): 77-81.

WWF. 2009. The cost of climate change: The story of Thorthormi glacial Lake in Bhutan rep. WWF.

Xin, W., L. Shiyin, G. Wanqin, and X. Junli. 2008. Assessment and simulation of glacier lake outburst floods. for Longbasaba and Pida lakes, China. Mountain Research and Development. 28 (3): 310-317. doi:http://dx.doi.org/10.1659/ mrd.0894.

$\mathrm{Xu}, \mathrm{D}$. 1988. Characteristics of debris flow caused by outburst of glacial lake in Boqu River, Xizang, China, 1981. GeoJournal 17 (4): 569-580.

Yamada, T. 1998. Glacier Lake and its outburst flood in the Nepal Himalaya. Japanese Society of Snow and Ice: Tokyo.

\section{Submit your manuscript to a SpringerOpen ${ }^{\circ}$ journal and benefit from:}

- Convenient online submission

- Rigorous peer review

- Open access: articles freely available online

- High visibility within the field

- Retaining the copyright to your article

Submit your next manuscript at $\gg$ springeropen.com 